the subject and to bring out its complications and difficulties in a perfectly orderly and systematic fashion. Wach report of a case includes a full description of the conditions present and a detailed account of the liandling of the situation. If the listening students in the conference knew but little of the subject, the reading of a report would not be unlike the reading of a lecture. But the listening students themselves have hand similar experiences, and, instean of sitting with minds dulled in receptivity, they are alert and actively following the account in order to question the reader on his incthods, his opinions, his results. And when the students fail to bring out all of the important points in the case, the instructor, a practical man, indicates the significance of the unnoted features. Such is the recognized value of this discussion of the actual conditions of practice that any question of the possibility of successfully applying the case method in medical instruction is here completely answered.

Undoubtedly the most brilliant example thus far of the use of cases in education is seen in the study of law. ${ }^{2}$ The ehange from the text-book to the case system wrought out in the IIarvard Law Selood has been called $\Lambda$ merical's greatest contribution to educational reform. 'The newer method has roused an ardor and a keemess of interest among the students such as was never known before. They leann their law not by dreary grubling at text-books or lecture notes, but by vigorously "threshing out a case" with one another. And for its methods and for its results the llarvard Law School is regarded by competent observers ${ }^{8}$ as perhajes the foremost centre of legal education in the English-speaking world.

'The case method is simply another application of the inductive method to teaching. 'I'he inductive methorl holds its strong position in elucation to-day because it requires of the student accurate judgment, close reasoning, precise expression and wise employment of his knowledge. It is a method which demands for a lone period a student's best endeavor's in the full use of all his faculties, but it rewards him with a strength and self-reliance unattainable in any other way. He learns, on the one hand, to avoid smartsess and clnptray diagnosis, and on the other, the routine thoughtlessness of the "plactical" physician. 'I'ho method is practical ; it will turn out practical men in the best meaning of that term.

\section{Elinical \&epartment.}

\section{A CASE OF RELAPSING FEVER.}

BY GLokak O. WA R1), Mr.1).,

Visiting Physician to the City Iospital and Memorial IJospital, Worcester, Mass.

RExarsing fever has not been epidemic in this country since 1869 , when it appeared in force in Philadelphia. 'The statisties and data of this epidemic, as investigated and reported by Parry, appear in stamdard medical literature. Sporadic cases are so rare as to be of exceeling interest. For this reason the author has chosen to report this case to the .JovirNAI. I wish to say at the ontset that this uncommon

2 See Keoner: Amerienn Law Revlew, xxvlii, for an excellent cocrunt of the workinge of the method in law. The writer is in debted to this article for suggestlons.

Nation, June 8, 1899. diagnosis was not inade because of any partiality therefor on the part of myself or my house officer, for we were forced to our conclusion in differential diagnosis by rigicl exclusion of other possible causes for the initial rise of temperature, and only convineed by the punctual appearance of the relapse:

'lhe patient, a young $A$ rmenian immigrant, eighteen years old, had just arrived, on $A$ ugust 9, 1899, with his mother, direct from 'Turkey-in- $\Lambda$ sia, via Fingland. They had been five weeks on the joumey, thirteen days of which were taken in the passage from some Enerlish port to New York. Neither he nor his mother conld speak a word of English. Ilence all data had to be obtained through the interpreter. Both were very sick on board ship, whether from mal-de-mer or an initial paroxysm of this fever I have not been alole to decide. But both mother and son were taken sick on the same day alter arrival in Worcester, with like symptoms. 'The former remained with friends for four days, when she entered the Memorial Iospital ; the latter entered the City Hospital at once.

'The crisis of the mother's fever occurred simultaneously with that of her son. Silse did not have relapse; but, in view of the evident intimate connection of the two cases, I think it fairly probable that the illness of both previous to landing may have been the initial run of the fever.

Angust 10th. 'The son, on his entrince into the City llospital, showed physiognomy characteristic of his race. Ilis previous medical history was nearative. His habits were good, and he denied venereal disease. Yesterday he had very severe headache and slight diarrhoa. Jater he had sevore chill, high fever, with much muscular pain. Later still, in the evening, he had profuse epistaxis, to eontrol which both nostrils laad to be plugged. $\Lambda$ this entrance, his temporature wats $104^{\circ}$, his pulse 100 , his respipation 22 . Ilis expression was dull and apathetic. Ilis skin was moist and very dark, suggesting jaundice. No erujtion of any kind was to be seen on his body. His pupils were normal. Ilis nostrils were plugged, and epistaxis followed any attempt to remove plugs. His tongue was dry, with brown coat. Sordes were on teeth, lips and gums. Ileart and lungs were negative. There was no tenderness of abdomen, but both liver and spleen were casily palpalle. Reflexes were sluggish. 'There was no elema. The urine was negative, the dia\%o reaction being absent. The patient was put on diet of liquids and ordered to have baths when temperature is ahove $102.5^{\circ}$. Jee eap was applied to heal. Strychnia, one-sixtieth grain every four hours. 'The temperature was ordered to be taken aud charted every four hours, an is our routine.

August 11 th. 'The Wirlal reaction is negative, and the diazo also. Plasmodium malarias was looked for but, was not found. Iceucocy tosis, 6,200 . Plugs were removerl from nostrils. No epistaxis followed. Temperature was still high, and patient was very apathetic but not delirious.

August 12th. 'I'emperature was still ahove $105^{\circ}$, and baths had little effect; pulse was not of good character. Spiritus frumenti, two drachms ordered every four hours. Slight "pistaxis. Patient looked ball.

August 13tll. Between eleven last night and three this morning, patient's temperature fell from $104.8^{\circ}$ to $97.2^{\circ}$ (nearly $8^{\circ}$ in less than four hours), and his 
pulse simultaneously fell from 110 to 68 . There were? no signs of collapse, and pulse was of grood character. Sweating was very profuse. Examination of chest was negative, as also was a second serum rxamination. Leucocytosis, 500. Patient brightened up during the

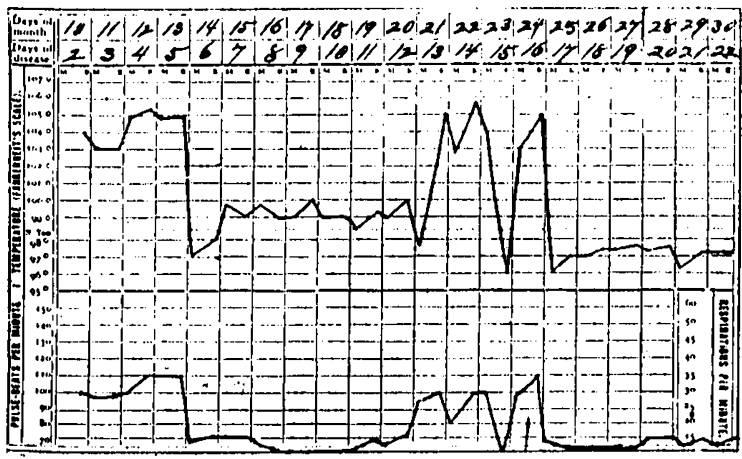

Chart of this case.

day and at night was feeling fairly comfortable. Constipation.

Angust 1 (ith. 'T'emperature soon rose to between 99 and $100^{\circ}$ and has continued so. Pulse has continued at aloout 70. Stimulants were omitted. Patient seems comfortable and takes interest in surroundings. Sluows signs of hunger. Denies subjective symptoms.

August 2 I st. l'atient has been feeling pretty comfortable sinec date of last note. Ilas been on diet of semi-solids, and has been allowed to sit. 11) a little in bed. Ilis skin appear's to have cleared as though he had been previously jamdiced. 'This afternom his temperature: shot up again from $97.8^{\circ}$ to $10.5 .5^{\circ}$ (rising nearly $8^{\circ}$ in less thane ight hours), hut without, marked subjective symptoms. Lencocytosis, 12,000.

August 23a. 'Temperature has remained persistently high since last note, until 11 A. M. to-rlay, when it fell by erisis from $105.5^{\circ}$ to $9\left(6^{\circ}\right.$ (falling $9.5^{\circ}$ in less than eight hours). He perspired very profusely and showed more evidence of collapse than in previous crises, so that some stimulant was griven. Ile complained of no symptoms, but during all this relapse lo has been very apathetic. 'The blood has, during this relapse, been examined raily for the spirillum (Obermeier and plasmodium malaria but without sucesss.

Altgust 24th. Between three and eleven this for':noon temperature rose aginin from $97^{\circ}$ to $105.6^{\circ}$, and,

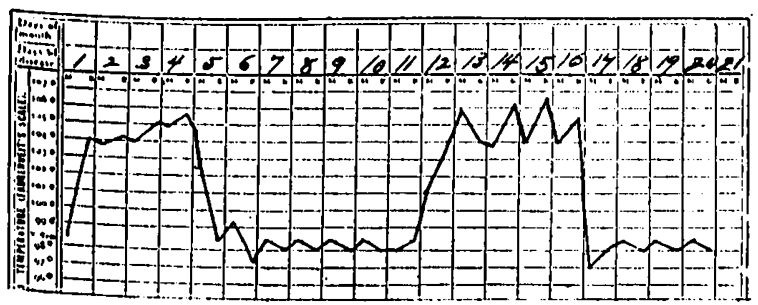

Chart of Murchison.

after continuing high for four hours, fell again to $95.6^{\circ}$ (a drop of $9^{\circ}$ in less than eight hours). 'This crisis, like the others, was accompanied by profuse sweating. atient is very apathetic, with fair pulse at 60.

August 25th. During last night the patient's tem- perature fell to $95.2^{\circ}$, but this forenoon it is $97^{\circ}$. The patient looks lorighter and has no symptoms.

September Ist. For the six clays after the last note, patient carried subnormal temperature, averaging about $97^{\circ}$, as recorded on four-hour charts. Yesterday and to-day the temperature has ranged in vieinity of $101^{\circ}$, without symptoms. l'atient has improved much in general condition. Complains much of hunger, and is to-rlay allowed to get up and eat house diet. Leucocyte (o)mt normal.

September 9th. ('onvalescence was steady from last date and patient was this day discharged well.

The above notes present a clinical picture fairly typical of relapsing fever. The temperature chart, is depieted in the anthorities, is so striking and so utterly mulike that of any other disease, that I wish to exhibit one from Murehison in comparison with that of the case above described. The "abrupt crisis, characterized by prodigious and sudden fall of temperature unequalled in any other condition of disease" (Murchison), is still more graphically shown by our four-hour chart, from which record l have verbally quoted in the notes. lBut if the chatt of the case just reviewed be properly superimposed on the ehart of Murchison they will be found to agree so strikingly that one can hardly suggest that they can arise from cases dissimilar in nature.

The failure to detoet the spirillum of Obermeier is not remarkable, as it was not looked for until the relapse, and it may not have been present. If the spirillum had been foumd, I think it would have been only regarded as evidence comfirmatory of a diagnosis otherwise well established by elinienl phenomena and at typical temperature record.

I wish to hereby acknowledge my indebtedness to my house plyssician, Dr. (Xeorge $\Lambda$. Dix, for his faitlful sturly of this case and for his careful clinical notes taken thereon.

\section{ON THE 'TREA'TMEN'T OF PAIN IN TABES DORSALIS; REPUR'T OF A CASL.}

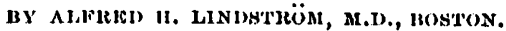

'Ine temporary amelioration and suppression of pain occurring during the erises of tabes dorsalis by the use of appropriate chemicals and clpugs is, no doubt, readily aceomplished. But the repeated and frequent use? of analgesic chemicals, especially coal-tar derivatives, is unquestionably deleterious to the general health of the patient, and since the sucesssful management of a tabetic patient demands the most careful attention to his gencenl health and his constitutional resistive powers, it is olvvious that such medication should be avoided as much as possible. Methods of diminishing and alleviating the intensely distressing pains of tabes, not involving injury to the general health, would therefore seem to morit attention. A number of mechanieal procedures have been suggested, and used with more or less snceess, such as surgical and postural stretching of the sciatic: nerves, suspension, various forms of counterirritation, inclucling the use of static sparks, other forms of electricity, direct pressure on the seiatic: nerve, the use of friction with ice, iee in other forms, hot baths, cold douchess and spray's to the spine, etc. Because of the marked suceess resulting from postural or mechanical stretching in the following case, its publication would seem justifinble. 